\title{
The validation of using serum iron increase to measure iron absorption in human subjects
}

\author{
Michael Hoppe, Lena Hulthén* and Leif Hallberg \\ Department of Clinical Nutrition, Institute of Internal Medicine, Sahlgrenska Academy at Göteborg University, Sweden \\ (Received 27 January 2004 - Revised 22 April 2004 - Accepted 22 April 2004)
}

\begin{abstract}
The objectives of the present study were to study the correlation between the change in serum $\mathrm{Fe}$ and $\mathrm{Fe}$ absorption when administering $100 \mathrm{mg} \mathrm{Fe}\left(\mathrm{as} \mathrm{FeSO}_{4}\right)$ orally, and to study the correlation between the absorption from a $3 \mathrm{mg}$ and a $100 \mathrm{mg} \mathrm{Fe}\left(\right.$ as $\left.\mathrm{FeSO} \mathrm{S}_{4}\right)$ dose. The study was conducted in a group of eleven male blood donors, without any evident infection, who had given blood 8 weeks before the study. On three consecutive mornings the subjects were served a wheat roll fortified with Fe. On the first $2 \mathrm{~d}$ the roll was fortified with $3 \mathrm{mg}$ Fe labelled with ${ }^{59} \mathrm{Fe}$; on day 3 the roll was fortified with $100 \mathrm{mg}$ Fe labelled with ${ }^{55} \mathrm{Fe}$. The serum Fe response to the $100 \mathrm{mg}$ dose was followed for $6 \mathrm{~h}$. Fe absorption was measured by whole-body counting. High correlations were seen between the absorption of Fe and the change in serum Fe after $100 \mathrm{mg} \mathrm{Fe}\left(r^{2} 0 \cdot 94, P<0 \cdot 001\right)$, between the absorption from $3 \mathrm{mg}$ and $100 \mathrm{mg} \mathrm{Fe}\left(r^{2} 0 \cdot 88, P<0 \cdot 001\right)$, and between the absorption from $3 \mathrm{mg} \mathrm{Fe}$ and change in serum $\mathrm{Fe}$ after $100 \mathrm{mg} \mathrm{Fe}\left(r^{2} 0.90, P<0.001\right)$. This strengthens the evidence that it is possible to use the change in serum $\mathrm{Fe}$ as a measure of $\mathrm{Fe}$ absorption, e.g. when establishing the relative bioavailability for Fe powders. The results also imply that the induced serum Fe increase following $100 \mathrm{mg}$ Fe added to a food could predict the Fe absorption of a small dose of Fe added to the same meal.
\end{abstract}

Serum iron: Iron absorption: Relative bioavailability: Elemental iron

Several methods can be used to measure Fe absorption from $\mathrm{Fe}$ compounds. Chemical Fe balance requires long balance periods and great care in analysing oral intake and faecal output of Fe. Thus, it is not feasible to use this method in practice. The introduction of radioisotopes has facilitated the measurement of $\mathrm{Fe}$ absorption especially when combined with whole-body counting to measure the total amount of retained radiolabelled Fe. A condition for such measurements is that the Fe compounds in the meal should have a bioavailability equivalent to the extrinsic radiolabelled $\mathrm{Fe}$ tracer and therefore that the meal can be homogeneously labelled, thus reflecting the true absorption. This homogeneously labelling ability is valid for most foods and Fe salts. Elemental Fe powders (e.g. metallic $\mathrm{Fe}$ ), which are insoluble in water and thus have unknown levels of bioavailability, are impossible to label homogeneously with an extrinsic radiolabelled Fe tracer.

Another approach in evaluating the bioavailability of different $\mathrm{Fe}$ compounds is to monitor the change in serum $\mathrm{Fe}$ after a standardised meal. Ekenved and colleagues (1976) found that when using radiolabelled $\mathrm{Fe}$ salts it was possible to relate the induced serum Fe increase to the true absorption of $\mathrm{Fe}$ measured by whole-body counting (Ekenved, 1976; Ekenved et al. 1976b). It was found that in a group of subjects there was a good agreement between the amount of absorbed $\mathrm{Fe}$ and the serum $\mathrm{Fe}$ increase.
However, since the amount of Fe present in common meals will give a low response in serum $\mathrm{Fe}$, higher $\mathrm{Fe}$ doses must be used. This begs question of the usefulness of this method when predicting the outcome in an actual fortification situation when low Fe doses are used. In the studies by Ekenved and colleagues $\mathrm{FeSO}_{4}$ was administered as solutions and tablets, which may differ from a meal-based situation. The first aim of the present study was to investigate the correlation between the change in serum $\mathrm{Fe}$ and the absolute Fe absorption measured with radioisotopes following administration of $100 \mathrm{mg} \mathrm{Fe}$ as $\mathrm{FeSO}_{4}$ in a meal. A second aim was to study the amount of $\mathrm{Fe}$ absorbed from a physiological dose of $\mathrm{Fe}(3 \mathrm{mg})$ in relation to the absorption from a pharmacological dose of Fe $(100 \mathrm{mg})$. Finally we also wanted to examine the absorption from a physiological dose of $\mathrm{Fe}(3 \mathrm{mg})$ and to compare it with the serum $\mathrm{Fe}$ increase from a pharmacological dose of Fe $(100 \mathrm{mg})$.

\section{Material and methods}

\section{Study design}

On three consecutive mornings eleven male subjects were served a wheat roll fortified with $\mathrm{FeSO}_{4}$. On the first $2 \mathrm{~d}$ the roll was fortified with $3 \mathrm{mg}$ Fe labelled with ${ }^{59} \mathrm{Fe}$, whereas on day 3 the roll was fortified with $100 \mathrm{mg}$ Fe labelled with ${ }^{55} \mathrm{Fe}$. The Fe absorption from both these doses as well 
as the serum $\mathrm{Fe}$ response for $6 \mathrm{~h}$ from the $100 \mathrm{mg}$ dose was studied. Variability in Fe status between subjects was controlled by using male subjects, without any evident infection, who had given blood 8 weeks before the study.

\section{Subjects and procedures}

Eleven healthy male subjects (aged 29-59 years), who had been regular blood donors for many years, took part in the present study. The subjects had given $450 \mathrm{ml}$ blood at a blood donor centre 8 weeks before attending the study. Before the study the subjects denied the use of medicine or $\mathrm{Fe}$ medication. All volunteers had been informed about the aim and procedures of the study, both verbally and in writing, before giving written consent to participate. The Ethics Committee of the Medical Faculty of Göteborg University approved the study. The subjects came to the laboratory on three consecutive mornings between 08.00 and 09.00 hours after fasting overnight. The subjects were not allowed to eat anything after 22.00 hours or drink anything after 24.00 hours the evening before. Each morning the subjects were served a meal consisting of one wheat roll fortified with $\mathrm{Fe}$ and $150 \mathrm{ml}$ water. The rolls, which were kept frozen until used, were baked from $40 \mathrm{~g}$ low-extraction wheat flour, $28.0 \mathrm{~g}$ water, $2.6 \mathrm{~g}$ yeast, $1.3 \mathrm{~g}$ sugar and $0.4 \mathrm{~g} \mathrm{NaCl}$ at our laboratory. The native $\mathrm{Fe}$ content in each roll before fortification was $0.15 \mathrm{mg}$. The weighed amounts of Fe were added through an incision in the roll.

On days 1 and 2 the subjects were served the wheat roll fortified with $3 \mathrm{mg} \mathrm{Fe}$ (as $\mathrm{FeSO}_{4}$ ) labelled with ${ }^{59} \mathrm{Fe}$. In order to reduce the influence from the day-to-day variation in absorption the mean absorption from these $2 \mathrm{~d}$ was later calculated. The subjects were then instructed not to eat or drink for the next $3 \mathrm{~h}$.

On day 3 an oral Fe tolerance test was performed and an absorption test using radioisotopes. The subjects were served the wheat roll fortified with $100 \mathrm{mg} \mathrm{Fe}\left(\right.$ as $\mathrm{FeSO}_{4}$ ) labelled with ${ }^{55} \mathrm{Fe}$. Before serving the meal, a plastic catheter was inserted into an anticubital vein and initial blood samples were taken to determine erythrocyte sedimentation rate, $\mathrm{C}$-reactive protein, initial serum $\mathrm{Fe}, \mathrm{Hb}$ concentration, serum ferritin and total Fe-binding capacity. In order to minimise the effect of haemolysis on the serum Fe analysis, the serum Fe blood samples were obtained without using a vacutainer and the blood was thus allowed to run freely into the test-tubes (Venoject ${ }^{\circledR} \mathrm{II}$, Autosep, Gel + Clot Act. Z; Terumo Europe NV, Leuven, Belgium). The handling of the blood samples and the serum $\mathrm{Fe}$ analysis was conducted as previously described (Hoppe et al. 2003). In order to follow the effect of oral Fe on serum Fe concentration, blood samples were drawn hourly for $6 \mathrm{~h}$ following the administration of the roll. Following the fifth blood sample, i.e. after $4 \mathrm{~h}$, two unsweetened rusks were served with $150 \mathrm{ml}$ coffee or tea. Between the blood sampling the subjects remained in our laboratory resting in a seated position. Whole-body counting was performed 10-14 d later and a blood sample was drawn in order to calculate the whole-body retention of both isotopes as previously described (Rossander, 1987).
The total received radioactivity for each subject was 74 $\mathrm{kBq}$ from ${ }^{55} \mathrm{Fe}$ and $37 \mathrm{kBq}$ from ${ }^{59} \mathrm{Fe}$.

\section{Statistical analyses}

After determining the increase in serum Fe following the meal, the area under the curve for the $6 \mathrm{~h}$ time period $\left(\mathrm{AUC}_{0-6 \mathrm{~h}}\right)$ was calculated using the trapezoidal rule. In a previous study we examined the increase in the basal serum $\mathrm{Fe}$ concentration in thirty-two subjects under the same conditions as this present study (Hoppe et al. 2003). It showed that the basal diurnal variation $\left(\mathrm{AUC}_{0-6 \mathrm{~h}} 18.7\right.$ (SEM 1.7) $\mu \mathrm{mol} \cdot \mathrm{h} / \mathrm{l}$ ) included in the serum $\mathrm{Fe}$ increase achieved by an oral dose of $\mathrm{Fe}$ must be subtracted from the primary data for serum $\mathrm{Fe}$ increase. Hence the $\mathrm{AUC}_{0-6 \mathrm{~h}}$ for each individual in this present study was adjusted for diurnal variation earlier seen in blood donors during exactly the same study conditions. The method used for comparing correlation was the Pearson correlation test. All $P$ values are two-tailed. The statistical program used was SPSS for Windows 10.0.5 (SPSS Inc., Chicago, IL, USA).

\section{Results}

\section{Exclusions}

From the present results three of the subject's data were excluded from further calculation. One subject was excluded because of the influence of infection. The other two subjects exceeded the total Fe-binding capacity after administration of $\mathrm{FeSO}_{4}$; this excluded their data from the calculation of the serum Fe change, but not of absorption. When the total Fe-binding capacity is exceeded, a part of the absorbed Fe will be deposited in the liver during the first passage (Wheby \& Umpierre, 1964).

\section{The iron absorption v. change in serum iron after $100 \mathrm{mg}$} iron

When $100 \mathrm{mg} \mathrm{Fe}$ as $\mathrm{FeSO}_{4}$ was administered together with the bread roll and water, the mean serum Fe $\mathrm{AUC}_{0-6 \mathrm{~h}}$ was 201.1 (SEM 33.8) $\mu \mathrm{mol} \cdot \mathrm{h} / \mathrm{l}$ and the mean absorption was 14.7 (SEM 2.0) \%. The squared correlation coefficient $\left(r^{2}\right)$ between Fe absorption from $100 \mathrm{mg}$ and the $\mathrm{AUC}_{0_{-}}$ $6 \mathrm{~h}$ for the serum Fe change was $0.94(P<0.001, n 8)$ (Fig. 1).

\section{The iron absorption from $3 \mathrm{mg}$ iron v. absorption from $100 \mathrm{mg}$ iron}

The mean absorption from $3 \mathrm{mg} \mathrm{Fe}$ was $55.4 \%$. When comparing this absorption with the mean absorption from $100 \mathrm{mg} \mathrm{Fe}, r^{2}$ was $0.88(P<0 \cdot 001, n 10)$ (Fig. 2).

The iron absorption from $3 \mathrm{mg}$ iron v. serum iron change from $100 \mathrm{mg}$ iron

The $r^{2}$ between $\mathrm{Fe}$ absorption from $3 \mathrm{mg}$ and the serum $\mathrm{Fe} \mathrm{AUC}_{0-6 \mathrm{~h}}$ after administering $100 \mathrm{mg} \mathrm{Fe}$ was 0.90 $(P<0.001, n 8)$. 


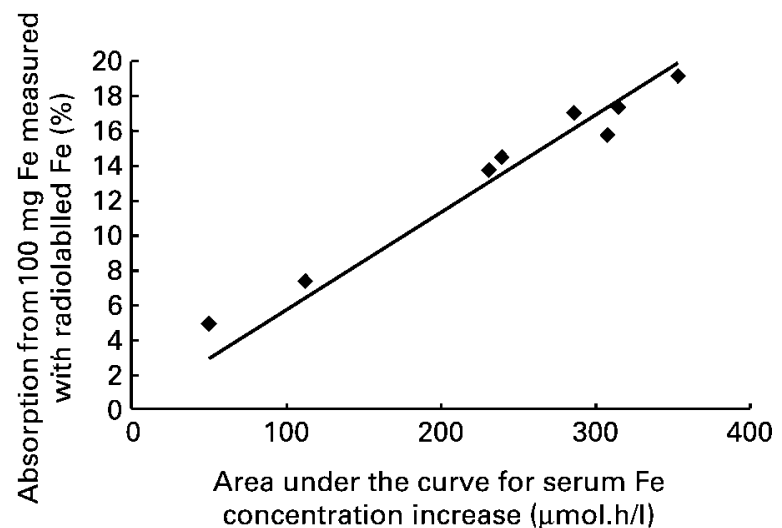

Fig. 1. Correlation between the serum iron change as the area under the curve for $6 \mathrm{~h}\left(\mathrm{AUC}_{0-6 \mathrm{~h}}\right)$ and absorption (\%) following administration of $100 \mathrm{mg}$ iron as $\mathrm{FeSO}_{4}\left(n 8 ; r^{2}\right.$ 0.94). The $\mathrm{AUC}_{0-6 \mathrm{~h}}$ was corrected for diurnal variation in serum iron concentration. For details of subjects and procedures, see p. 486.

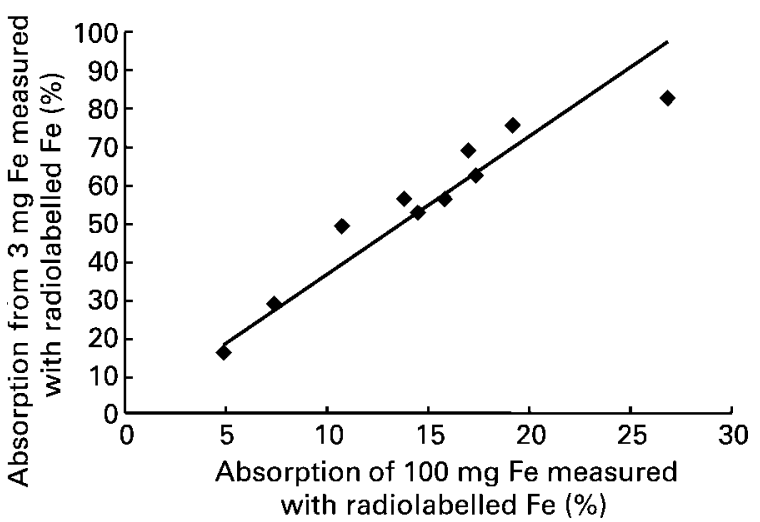

Fig. 2. Correlation between the absorption (\%) following administration of $3 \mathrm{mg}$ iron and the absorption (\%) following administration of $100 \mathrm{mg}$ iron as $\mathrm{FeSO}_{4}\left(n 10 ; r^{2} 0.88\right)$. For details of subjects and procedures, see p. 486.
The haematological variables and Fe absorption results are presented in Table 1.

\section{Discussion}

The present findings strengthen our earlier conclusion that monitoring serum Fe increase may be a reliable and simple method to determine the relative bioavailability of various elemental $\mathrm{Fe}$ powders in relation to $\mathrm{FeSO}_{4}$ (Hoppe et al. 2003). However, in order to induce a serum Fe response that differs significantly from the basal variation, a pharmacological dose of Fe is needed. This could give rise to arguments against using this method to determine relative bioavailability, since the response from $100 \mathrm{mg}$ Fe perhaps cannot be translated into an actual fortification situation when smaller physiological doses are used. So, is the relative bioavailability for a fortification $\mathrm{Fe}$ powder obtained with this pharmacological dose of Fe really the same when a smaller dose is used? To investigate this we conducted an experiment where the absorption from a $3 \mathrm{mg}$ and a $100 \mathrm{mg}$ Fe dose, as well as the serum Fe response from the $100 \mathrm{mg}$ dose, were studied. The correlations between the absorption and the change in serum $\mathrm{Fe}$ from $100 \mathrm{mg}$, the absorption from $3 \mathrm{mg} \mathrm{Fe}$ and the $100 \mathrm{mg} \mathrm{Fe}$ dose, and also between the absorption from $3 \mathrm{mg} F e$ and the change in serum $\mathrm{Fe}$ after $100 \mathrm{mg}$, were good.

When using the double-isotope technique and wholebody counting, a relative bioavailability based on absorption from $100 \mathrm{mg} \mathrm{Fe}$ is as valid as a relative bioavailability based on absorption from $3 \mathrm{mg}$ Fe. The present results show that the relative bioavailability based on serum $\mathrm{Fe} \mathrm{AUC}_{0-6 \mathrm{~h}}$ when administering $100 \mathrm{mg} \mathrm{Fe}$ also is valid, since $\mathrm{AUC}_{0-6 \mathrm{~h}}$ correlates with absorption from $100 \mathrm{mg} \mathrm{Fe}$ (Fig. 1). Furthermore, the absorption from $100 \mathrm{mg} \mathrm{Fe}$, as well as the $\mathrm{AUC}_{0_{-} 6 \mathrm{~h}}$, correlates with absorption from $3 \mathrm{mg}$ Fe (Fig. 2 and p. 486). These results make it highly probable that a relative bioavailability

Table 1. Initial haematological variables and iron absorption from $100 \mathrm{mg}$ iron and $3 \mathrm{mg}$ iron as $\mathrm{FeSO}_{4}$ *

\begin{tabular}{|c|c|c|c|c|c|c|c|c|c|c|c|c|c|}
\hline \multirow{3}{*}{$\begin{array}{l}\text { Subject no. } \\
\text { Time (h)... }\end{array}$} & \multicolumn{12}{|c|}{$100 \mathrm{mg} \mathrm{Fe}$} & \multirow{3}{*}{$\begin{array}{c}3 \mathrm{mg} \mathrm{Fe} \\
\begin{array}{c}\text { Absorption } \\
(\%)\end{array}\end{array}$} \\
\hline & \multicolumn{7}{|c|}{ Serum-Fe $(\mu \mathrm{mol} / \mathrm{l}) \dagger$} & \multirow{2}{*}{$\begin{array}{c}\text { TIBC } \\
(\mu \mathrm{mol} / \mathrm{I})\end{array}$} & \multirow{2}{*}{$\begin{array}{l}\text { Ferritin } \\
(\mu g / l)\end{array}$} & \multirow{2}{*}{$\begin{array}{l}\mathrm{Hb} \\
(\mathrm{g} / \mathrm{l})\end{array}$} & \multirow{2}{*}{$\begin{array}{l}A^{A} C_{0-6 h} \\
(\mu \mathrm{mol} \cdot \mathrm{h} / \mathrm{l})\end{array}$} & \multirow{2}{*}{$\begin{array}{c}\text { Absorption } \\
(\%)\end{array}$} & \\
\hline & 0 & 1 & 2 & 3 & 4 & 5 & 6 & & & & & & \\
\hline 1 & 0.0 & $39 \cdot 2$ & $67 \cdot 7$ & 73.9 & $72 \cdot 5$ & $68 \cdot 1$ & $64 \cdot 3$ & 81 & 11 & 149 & 353.5 & $19 \cdot 1$ & $75 \cdot 3$ \\
\hline $2 \ddagger$ & 0.0 & $26 \cdot 2$ & $42 \cdot 4$ & $41 \cdot 7$ & $43 \cdot 5$ & 34.4 & $29 \cdot 5$ & 67 & 11 & 157 & $203 \cdot 0 \ddagger$ & $10 \cdot 7$ & $49 \cdot 1$ \\
\hline 3 & 0.0 & $30 \cdot 4$ & $51 \cdot 5$ & 66.5 & $67 \cdot 0$ & $67 \cdot 0$ & 64.9 & 75 & 7 & 150 & 314.8 & $17 \cdot 3$ & $62 \cdot 4$ \\
\hline 5 & 0.0 & $25 \cdot 7$ & $41 \cdot 2$ & $51 \cdot 2$ & $48 \cdot 7$ & $48 \cdot 8$ & $47 \cdot 4$ & 72 & 15 & 151 & 239.3 & $14 \cdot 4$ & $52 \cdot 8$ \\
\hline 6 & 0.0 & 5.5 & 8.5 & $9 \cdot 7$ & $10 \cdot 4$ & $10 \cdot 9$ & $10 \cdot 5$ & 58 & 51 & 156 & $50 \cdot 3$ & 4.9 & $16 \cdot 0$ \\
\hline $7 \ddagger$ & 0.0 & $41 \cdot 6$ & $69 \cdot 2$ & $75 \cdot 1$ & $71 \cdot 3$ & $70 \cdot 8$ & $70 \cdot 9$ & 78 & 8 & 151 & $363.5 \ddagger$ & $26 \cdot 8$ & $82 \cdot 4$ \\
\hline 8 & 0.0 & 33.7 & 54.9 & $65 \cdot 0$ & $63 \cdot 3$ & 61.8 & $58 \cdot 3$ & 74 & 16 & 151 & $307 \cdot 8$ & $15 \cdot 8$ & $56 \cdot 2$ \\
\hline 9 & 0.0 & $38 \cdot 8$ & $50 \cdot 6$ & $47 \cdot 2$ & 41.5 & $37 \cdot 1$ & $32 \cdot 8$ & 82 & 21 & 160 & $231 \cdot 7$ & $13 \cdot 8$ & 55.9 \\
\hline 10 & 0.0 & $33 \cdot 2$ & 52.4 & $59 \cdot 9$ & 57.4 & $56 \cdot 5$ & $53 \cdot 0$ & 76 & 16 & 157 & $286 \cdot 0$ & $17 \cdot 0$ & $68 \cdot 8$ \\
\hline $11 \S$ & 0.0 & $9 \cdot 3$ & $17 \cdot 1$ & $25 \cdot 6$ & $22 \cdot 6$ & 23.5 & $19 \cdot 6$ & 65 & 18 & 147 & $107 \cdot 8 \S$ & $8 \cdot 1 \S$ & $62 \cdot 4$ \\
\hline Mean & 0.0 & 26.99 & 42.90 & 49.37 & $48 \cdot 33$ & 46.96 & $44 \cdot 78$ & $72 \cdot 4$ & $19 \cdot 8$ & 153.4 & 236.95 & $14 \cdot 73$ & 55.44 \\
\hline
\end{tabular}

TIBC, total Fe-binding capacity; $\mathrm{AUC}_{0-6 \mathrm{~h}}$, area under the curve for $0-6 \mathrm{~h}$

${ }^{*}$ For details of subjects and procedures, see p. 486.

† Increase in serum Fe concentration for $6 \mathrm{~h}$ following administration of $100 \mathrm{mg}$ Fe; values were corrected for diurnal variation in serum Fe.

$\ddagger$ Subject was excluded from calculation of mean serum Fe AUC due to exceeded TIBC.

§ Subject was excluded from calculation of mean serum Fe AUC and absorption from $100 \mathrm{mg}$ due to infection. 
obtained with the serum Fe method, using $100 \mathrm{mg} \mathrm{Fe}$, is equivalently valid in a fortification situation using lower levels of Fe, e.g. $3 \mathrm{mg}$.

Subject no. 7 was an exception from the strong correlation between the absorption from the two Fe doses. This subject had the highest absorption from the $3 \mathrm{mg}$ dose $(82.4 \%)$. Nevertheless in order to end up on the correlation line, the absorption had to be even greater. One possible explanation for this is that when approaching $100 \%$ absorption the dose-response relationship deviates. The reason for this could be that when absorption proceeds the remaining $\mathrm{Fe}$ in the lumen decreases. This in turn makes it more and more difficult for the brush border Fe transporters (e.g. the divalent metal transporter 1) on the mucosa cells to detect, attract and transport the $\mathrm{Fe}$ atoms inside the enterocytes.

The Fe tolerance test, i.e. the serum Fe method, has earlier mostly been used to study Fe absorption from Fe preparations for pharmaceutical purposes and for diagnosis of Fe deficiency (Ekenved, 1976; Ekenved et al. 1976a; Nielsen et al. 1976; Kelsey et al. 1991). When the purpose has been to evaluate the usefulness of this method in discriminating between normal and Fe-deficient individuals, the small-dose Fe tolerance test (using Fe doses of 5-20 mg) is the most commonly used (Crosby \& O'Neil-Cutting, 1984; Costa et al. 1991; Joosten et al. 1997; Jensen et al. 1998, 1999). The small-dose Fe tolerance test is based on the fact that low doses of Fe do not have the potential to induce any changes in serum $\mathrm{Fe}$ in subjects with normal $\mathrm{Fe}$ status. In order to do this, the subjects must have some degree of Fe deficiency and hence a higher Fe absorption ability. The utilisation of the serum $\mathrm{Fe}$ method on determining the relative bioavailability of elemental $\mathrm{Fe}$ used for fortification has to our knowledge only been done in human subjects once before (Gonzalez et al. 2001). However, in our hands the serum Fe method has recently, and for the first time, been used in a meal situation to determine the relative bioaviailability of elemental $\mathrm{Fe}$ powders (Hoppe et al. 2003).

In summary, the present results strengthen our earlier conclusion that monitoring changes in serum $\mathrm{Fe}$ as a measure of $\mathrm{Fe}$ absorption is possible. Furthermore, the induced increase in serum Fe following $100 \mathrm{mg} F$ added to a food could predict the Fe absorption of a small dose of Fe added to the same meal.

\section{References}

Costa A, Liberato LN, Palestra P \& Barosi G (1991) Small-dose iron tolerance test and body iron content in normal subjects. Eur J Haematol 46, 152-157.

Crosby WH \& O'Neil-Cutting MA (1984) A small-dose iron tolerance test as an indicator of mild iron deficiency. $J \mathrm{Am}$ Med Assoc 251, 1986-1987.

Ekenved G (1976) Absorption from different types of iron tablets - correlation between serum iron increase in total absorption of iron. Scand J Haematol 28, Suppl., 51-63.

Ekenved G, Arvidsson B \& Solvell L (1976a) Influence of food on the absorption from different types of iron tablets. Scand J Haematol 28, Suppl., 79-88.

Ekenved G, Norrby A \& Solvell L (1976b) Serum iron increase as a measure of iron absorption - studies on the correlation with total absorption. Scand J Haematol 28, Suppl., 31-49.

Gonzalez H, Mendoza C \& Viteri FE (2001) Absorption of unlabeled reduced iron of small particle size from a commercial source. A method to predict absorption of unlabeled iron compounds in humans. Arch Latinoam Nutr 51, 217-224.

Hoppe M, Hulthén L \& Hallberg L (2003) Serum iron concentration as a tool to measure relative iron absorption from elemental iron powders. Scand J Clin Lab Invest 63, 489-496.

Jensen NM, Brandsborg M, Boesen AM, Yde H \& Dahlerup JF (1998) Low-dose oral iron absorption test: establishment of a reference interval. Scand J Clin Lab Invest 58, 511-519.

Jensen NM, Brandsborg M, Boesen AM, Yde H \& Dahlerup JF (1999) Low-dose oral iron absorption test in anaemic patients with and without iron deficiency determined by bone marrow iron content. Eur J Haematol 63, 103-111.

Joosten E, Vander Elst B \& Billen J (1997) Small-dose oral iron absorption test in anaemic and non-anaemic elderly hospitalized patients. Eur J Haematol 58, 99-103.

Kelsey SM, Hider RC, Bloor JR, Blake DR, Gutteridge CN \& Newland AC (1991) Absorption of low and therapeutic doses of ferric maltol, a novel ferric iron compound, in iron deficient subjects using a single dose iron absorption test. J Clin Pharm Ther 16, 117-122.

Nielsen JB, Ikkala E, Solvell L, Bjorn-Rasmussen E \& Ekenved G (1976) Absorption of iron from slow-release and rapidly-disintegrating tablets - a comparative study in normal subjects, blood donors and subjects with iron deficiency anaemia. Scand $J$ Haematol 28, Suppl., 89-97.

Rossander L (1987) Effect of dietary fiber on iron absorption in man. Scand J Gastroenterol 129, Suppl., 68-72.

Wheby MS \& Umpierre G (1964) Effect of transferrin saturation on iron absorption in man. $N$ Engl J Med 271, 1391-1395. 